\title{
O Cinema Português, o Transtemporal e o Mito
} Sara Castelo Branco ${ }^{1}$

O cinema detém uma complexa relação com a temporalidade, circunscrevendo atributos e conexões espácio-temporais singulares, onde se inclui a capacidade de inverter o tempo, colocando o passado, o presente e o futuro em osmose, reproduzindo, assim, como o pretendem alguns, os próprios mecanismos do pensamento humano, o que faz do cinema uma "forma pensante" por excelência. A cada projeção cinematográfica, o passado atualiza-se no presente, e, contínua no porvir, havendo igualmente uma transitoriedade inerente à sua imagem, que se presentifica, mas, também, passa imediatamente a ser passado. Neste sentido, podemos pensar o cinema como algo intrinsecamente transtemporal, na medida em que desconstrói uma representação cronológica e sequencial do tempo, reconfigurando-o através de uma associação entre várias temporalidades.

Segundo o sociólogo Eviatar Zerubavel, todos os sujeitos pertencem a "comunidades mnemónicas", coletividades que podem ser de domínio micro-social como as famílias ou macrossocial como as nações, e se concebem a partir da pertença a uma mesma entidade ao longo do tempo (Zerubavel 2003, 60). Assim, a pertença a uma nação implica a comunhão de uma memória e de referências e características comuns a um passado coletivo, tratando-se de uma "comunidade imaginária formada pelos mortos, pelos vivos e pelos que ainda não nasceram, que se mantém unida graças a uma cola chamada memória." (Ash 2005). Desta forma, podemos afirmar que a transtemporalidade é inerente ao conceito de identidade nacional, porquanto assenta no conjunto de particularidades coletivas que sobreviveram do passado até ao presente, projetando-se no futuro, na medida em que se apresentam como inerentes a um ser nacional e a um destino coletivo.

Partindo precisamente de uma reflexão acerca destas particularidades identitárias no contexto português, Eduardo Lourenço - em obras como O Labirinto da Saudade - Psicanálise Mítica do Destino Português (1978) ou Portugal como Destino seguido de Mitologia da Saudade (1999) - concebeu um levantamento e uma decomposição dos mitos e ficções do imaginário identitário nacional, onde a especificidade portuguesa não estaria, propriamente, na criação de uma imagem "ideal" de si mesma, mas no fato dos portugueses viverem em função dessa "imagem irrealista", gerando uma espécie de identidade hiperbólica e um cativeiro contínuo num passado-futuro.

\footnotetext{
${ }^{1}$ Universidade do Porto, Faculdade de Belas Artes, 4049-021 Porto, Portugal.
} 
Segundo Lourenço, a perda da independência portuguesa (1580) na sequência da crise sucessória ditada pela derrota em Alcácer-Quibir, tal como o consequente interregno filipino até 1640, tornou claro que "a nossa razão de ser, a raiz de toda a esperança, era o termos sido" (Lourenço 2007, 22). A memória portuguesa teria incorporado, assim, uma espécie de "não-tempo". Desta forma, uma obsessão pelo passado coexistiria com uma espera utópica pelo futuro, vivendo-se num presente suspenso e transtemporal, visível no fenómeno do sebastianismo: "Descontentes com o presente, mortos como existência nacional imediata, nós começámos a sonhar simultaneamente o futuro e o passado" (Lourenço 2007, 22). Desta forma, contrariando a historiografia moderna caracterizada por uma "temporalidade irreversível desvinculada do seu suporte simbólico e transtemporal" (Lourenço 2001, 20), o sebastianismo iria inscreverse na ordem do desejo e do sonho, e, por conseguinte no futuro, pois "o tempo que, resumindo todos os tempos, lhe dá sentido é o de uma espera messiânica, real ou simbólica” (Lourenço 2001, 20). Questionando assim o destino coletivo em devir - e como ele foi miticamente circunscrito e discernido pela literatura portuguesa -, o autor defende que com o fim do Império os portugueses deveriam finalmente reconhecer-se como "apenas um povo entre os povos. Que deu a volta ao mundo para tomar a medida da sua maravilhosa imperfeição" (Lourenço 2007, 83), podendo, finalmente, deixar de viver um presente encoberto pelo passado e pela perspetiva de um futuro messiânico.

Neste sentido, a investigação realizada em O Cinema Português, o Transtemporal e o Mito parte do cruzamento destas dimensões transtemporais, para centrar a sua interrogação no cinema português. Se, inicialmente, houve um cinema embebido de desígnio históricopatriótico que, ao serviço da Política do Espírito, fortaleceu estas mitologias - tais como o sebastianismo, o imperialismo, a imponência dos grandes heróis e acontecimentos nacionais, etc. -, posteriormente, estas mesmas representações iriam ser exorcizadas e desconstruídas por uma série de filmes durante os anos finais e posteriores ao Estado Novo. Desta forma, partindo de uma abordagem diacrónica, esta investigação reflete sobre de que forma algumas das mitologias presentes nas obras literárias referidas por Eduardo Lourenço evoluíram até representações imagéticas no séculos XX, meditando assim sobre o presente e o passado do país, através de um duplo movimento de construção e desconstrução.

\section{A Personificação da Nação em Camões}

Antes de assumir a direção do Secretariado de Propaganda Nacional (SPN/SNI), António Ferro, o grande obreiro da política cultural e propagandística do Estado Novo entre 1933 e 1949, publicou um artigo denominado "Política do Espírito" (1932), que versava sobre a 
construção de um desígnio de nação através da cultura, cristalizando uma arte nacional, cuja reflexão conciliava dimensões como o sebastianismo, o espiritualismo ou o nacionalismo cultural. Através de uma imagem da História nacionalista e uniforme - que surgia assistida por marcas atemporais, como os mitos que constituíram a identidade portuguesa -, o regime autoritário instrumentalizou a pedagogia e a propaganda, sendo o cinema um aparelho basilar na "construção da própria história" (Torgal 2009, 16), sobretudo através de obras que retratavam os feitos e as glórias mais longínquas.

O Estado Novo envergava assim uma política historicista, partilhando um imaginário coletivo de representações simbólicas comuns e a representação de uma identidade que foi "forjada na mitologia, podendo - por intermédio da disciplina histórica, alfobre do culto patriótico - prolongar-se até à atualidade" (Ramos 1999, 73). Durante as primeiras décadas do Estado Novo, o cinema português, sobretudo a comédia - dos "alfaiates e costureiras, estudantes e boémios, varinas e empregados de balcão, aristocratas arruinados e galãs marialvas" (Grilo 2006, 15) -, cujo fermento era a modéstia, os respeitos morais e os bons costumes, detinha uma mensagem quase sempre branda e inofensiva, e, assim, matizada no salazarismo. Contudo, ainda que, costumadamente, estes filmes sejam aludidos como simbólicos de uma evasão nacional dos problemas reais da ideologia social do Estado Novo, esta conexão é mais complexa do que aparenta ser, pois quase nunca qualquer dirigismo favoreceu a proveniência destas produções. Aliás, António Ferro tinha uma certa repulsa pelo género da comédia que considerava ser "o cancro do cinema nacional, afora duas ou três excepções” (Ferro 1950, 64-65).

Neste sentido, o Estado Novo "não queria ficar cinematograficamente imortalizado apenas por algumas piadas" (Costa 1991, 95), interessava, assim, pela batuta do António Ferro, privilegiar um cinema de exaltação histórica e de elevação do presente - onde se impusesse a teatralização dos ideais do Estado Novo -, através da imagem dos pretéritos apoteóticos nacionais, que apenas caberiam num género com a seriedade do histórico-literário. Assim, elogiando a História e Império português, o cinema privilegiado do regime iria cumprir no século XX o que a literatura antes erigiu na fixação de uma mitologia nacional, não deixando a literatura de continuar a ocupar este mesmo lugar de (re)produção mitológica da nação. A ampliação diegética do mito histórico-messiânico evoluiria, assim, até representações imagéticas presentes num cinema de desígnio histórico-patriótico ao serviço da Política do Espírito.

É neste contexto que Leitão de Barros - com um despacho do próprio Salazar, sobre o interesse nacional desta obra - realiza $\mathrm{Ca}$ mões - Erros Meus, Má Fortuna, Amor Ardente (1945), filme que selecionava alguns episódios da vida de Camões, construindo uma tese subjetiva que destacava a dimensão lendária do poeta. $\mathrm{O}$ filme explorava um fervor nacionalista ao basear-se na extensão mitológica 
da personagem e dos acontecimentos, inscrevendo-se assim na aceção de Eduardo Lourenço de que: "Portugal tem uma hiperidentidade porque tem um défice de identidade real. Como tem um défice de identidade, compensa-a no plano imaginário" (Silva 1992, 38).

Neste sentido, um dos episódios mais declaradamente apologistas da política historicista do Estado Novo no filme, sobrevém perante dois símbolos da arte portuguesa ao serviço da Nação. Antes de partir para as Índias, Camões tem uma revelação ao olhar para as imagens das Tapeçarias de Pastrana e dos Painéis de São Vicente de Fora, alegorias maiores às proezas e heróis da História nacional. A criação das Tapeçarias de Pastrana foi ordenada por D. Afonso V, no século XV, para documentar as vitórias na tomada de cidades no Norte de África. Nas quatro tapeçarias, D. Afonso V apenas não aparece retratado na primeira, sendo, portanto, uma obra de auto-glorificação do governante e da Dinastia de Avis, cumprindo assim em imagem o que, em parte, Os Lusíadas cumprem em palavra. Os Painéis de São Vicente de Fora, da autoria do pintor Nuno Gonçalves, são identicamente uma obra do reinado de D. Afonso V. As pinturas retratam 58 personagens a rodear a dupla figuração de São Vicente (patrono da expansão militar portuguesa no Magrebe), e representam a Corte e os vários grupos sociais do país. No filme, quando Camões se encontra com estas obras e as percorre com o olhar, ouvimos uma profética voz entoando os primeiros versos d'Os Lusíadas, a que Camões acrescentará:

"Só agora consegui compreendê-los, há neles uma história que ainda não foi cantada, hei-de eu cantá-la. (...) Lá do longe, amarei melhor a minha pátria, com tantas saudades dela. De lá trarei um canto, um canto em que espalharei por toda a parte a glória de Portugal."

A cena termina com imagens do Mosteiro dos Jerónimos, do Padrão dos Descobrimentos e da Torre de Belém, seguidas pela visão do barco que leva Camões para as Índias. Desta forma, irão ser as representações das vitórias do passado, e dos símbolos arquitetónicos da expansão marítima portuguesa, a inspirar a viagem de Camões e a sua obra.

Luís de Pina afirma não ter dúvidas de que a visão histórica mais essencial do filme está na concepção de Camões enquanto imagem de Portugal. A nação irá ser assim sumulada na vida do poeta que, vivendo uma primeira fase aventurosa, entra depois em decadência, morrendo quando a Pátria "morre". No entanto, ao cessar, Camões anuncia o futuro renascimento do país: à sua imagem num estado moribundo no leito da morte são sobrepostas visões da Batalha de Alcácer-Quibir, assistindo-se depois "à conversão gloriosa da própria história de Portugal, simbolizada pelo levantar das bandeiras por entre o nevoeiro sebastianista" (Torgal 2001, 70). As datas e as bandeiras respeitam à Restauração da Independência (1640), à expulsão das tropas francesas (1810), à guerra de pacificação em Moçambique e da batalha de Chaimite (1895) e às celebrações do 
Duplo Centenário da Fundação da Nacionalidade e da Restauração, organizadas pelo Estado Novo (1940).

Para Eduardo Lourenço, toda a narrativa orgástica desta ficção coletiva teve como compositor original Luís de Camões, que foi o responsável pela existência e perpetuação da memória nacional: "o verdadeiro Sebastião é o texto dos Lusíadas que desde então - embora só o romantismo lhe confira esse estatuto - se converteu na referência icónica da cultura portuguesa" (Lourenço 2007, 19). Em Camões, o rei D. Sebastião elogia Os Lusíadas desejando ingenuamente que seja o poeta a cantar os feitos vitoriosos dessa batalha próxima de Alcácer-Quibir. Porém, no final desse encontro, o que observamos é uma imagem de Camões coroado. Neste sentido, por meio da sua obra, o poeta será o último portador do triunfo nacional, que terá um término com a derrota de D. Sebastião.

Os Lusíadas fixaram, assim, a primeira "identidade e matriz" (Lourenço 2001, 67) da futura mitologia portuguesa, que seria afetada e reinventada pelos acontecimentos que sucederiam em AlcácerQuibir. Esta configuração de Camões enquanto criador do mito nacional e da esperança num porvir extraordinário, ganha ecos na própria imagem com que Salazar se encobriria. A ação do Estado Novo, e do seu dirigente, iria confundir-se com a da própria Nação, pois o Estado Novo não se limitaria a ser "mais um regime político, mas a tradução institucional e ontológica do verdadeiro destino da nação" (Rosas 1998, 13). A auto-mitificação nacional, segundo enuncia Lourenço, encontraria assim um cume com o regime autoritário, tornando-se na ficção oficial do Portugal salazarista, o último "que se assumiu e viveu como um destino" (Lourenço 2001, 67). Através de uma política identitária transtemporalizada, Salazar utilizaria um processo de legitimação pela História, travestindo-se como herdeiro natural dos grandes líderes e heróis nacionais (como Viriato, D. Afonso Henriques ou Camões), e assumindo-se portanto como o continuador de um devir português imperial, representado exemplarmente naquela última bandeira de 1940 que finaliza o filme, e que solidifica o caráter transtemporal da obra.

\section{O Sebastianismo e Frei Luís de Sousa}

O Estado Novo foi o descendente tardio de um certo neogarrettismo ou neorromantismo (Torgal 2009), movimentos que, no final do século XIX, vieram reaclamar os românticos de início de oitocentos, num movimento de consolação face ao sentimento de humilhação e orfandade identitária ditados pelo Ultimatum Inglês (1890). O estímulo dado à leitura destes romances oitocentistas pelo Estado Novo autorizou e impulsionou a conceção de várias versões teatrais e cinematográficas, adaptações que traziam para o palco ou para o ecrã uma imagem estereotipada e ideada que assentava no regime. Neste sentido, podemos atentar ao exemplo da adaptação de António Lopes 
Ribeiro da obra Frei Luís de Sousa (1956), a peça homónima de Almeida Garrett, autor legitimado por Salazar como inspiração para as conceções do regime, onde "o método de 'colagem' descontextualizada servia, de forma exemplar, para pôr em prática a estratégia da “conversão'” (Torgal 2009, 229).

Frei Luís de Sousa narra o drama de D. Madalena, uma senhora nobre que julgando-se viúva, após o desaparecimento do marido D. João em Alcácer-Quibir, se casa com D. Manuel, e com este tem uma filha, D. Maria. Apesar de vinte anos passados desde o desaparecimento de D. João, D. Madalena vive atormentada pelo seu regresso, temores e presságios que se irão agudizar com o retorno à sua antiga morada devido à resistência de $\mathrm{D}$. Manuel à dominação espanhola. No final, a fatalidade do regresso de D. João levará D. Madalena e D. Manuel a ingressarem num convento de forma a enfrentarem a ignomínia da sua bigamia e a condição ilegítima da filha, que desarmada pela desonra do seu nascimento irá morrer na mesma igreja que converte os pais.

Segundo Eduardo Lourenço, as obras de Garrett e Herculano iriam discutir o passado e o porvir nacional através de uma inscrição na História, fundando uma tradição cultural e uma identidade histórica singularmente portuguesa:

"O que Herculano fundou em prosa epicamente nostálgica, Garrett fundou em nostalgia elegíaca, colocando Camões, de uma vez para sempre, no centro da nova mitologia pátria, pátria de feitos (...). É ele o verdadeiro rei Sebastião ou, pelo menos o seu livro o novo Gral, pois foi por via dele, como no seu drama Frei Luís de Sousa é manifesto, que a esperança da ressurreição pátria se conservou" (Lourenço 2001, 31-32).

Desta forma, a notoriedade dada a Camões por Garrett é reiterada no filme: o encadeamento original da peça é alterado, reunindo no início as duas referências diretas a Camões, que existem fragmentadas no texto original. Após breves imagens da finalizada Batalha de Alcácer-Quibir, o filme principia com o diálogo de uma cena que está presente quase a meio da peça, quando D. Maria e Telmo se confrontam com os retratos de D. Sebastião, Camões e D. João, as três figuras que, embora fisicamente ausentes, vão contextualizando e determinando o timbre da história. Se na peça todos os retratos sofrem, a certo momento, uma contemplação pelas personagens, atuando sobre elas - são a reprodução material dessas figuras espectrais e do que elas representam -, a segunda cena do filme mostra as personagens em lugar de contemplação do rio: o espaço simultaneamente vácuo e absoluto, onde, para além dele, essas presenças se perderam e a sua memória ficou abrigada, e só dali poderão regressar. Numa alusão sebastianista, todo este diálogo dirá respeito a Camões. O filme retoma depois o encadeamento original da peça, através de uma relação intertextual, pois as primeiras palavras entoadas por D. Madalena são 
dois versos sintomáticos do episódio sobre Inês de Castro d'Os Lusíadas.

Para Garrett, o devir e o renascimento da cultura nacional está na reescrita do seu passado no presente, ou da leitura de uma presença desse passado no presente, pois "unindo historicamente, e não acidental ou liricamente, Portugal e a saudade, Garrett instaurou a primeira mitologia cultural portuguesa sem transcendência" (Lourenço 2001, 32). O sebastianismo é o lugar por onde se cruzam todos os caminhos de Frei Luís de Sousa, pois D. Sebastião e D. João confundem-se, ainda que a cada um caiba uma espera distinta, pois a chegada do rei significa o regresso do líder messiânico, todavia, a vinda do cavaleiro, o desmembramento familiar. A essência desta encruzilhada sebastianista está perfeitamente presente naquele que é um dos diálogos mais célebres do teatro português: à questão "quem és tu, romeiro?", o viajante, de forma enigmática e aterradora, responderá "ninguém!" - o regresso transforma-se na constatação do vazio.

É, precisamente, essa interrogação, o “Quem és tu?”, que, cinquenta anos depois, denominará um filme de João Botelho, que encontra nesta designação esse vazio sebastianista, mas, igualmente, a tentativa de reanimar o espírito original da peça. No filme, a narrativa da peça é precedida por um prólogo constituído por vários textos, narrados quase sempre por D. Sebastião, onde se afiguram imagens devaneadoras sobre a história do rei e a origem do sebastianismo. Embora os episódios de maior peso dramático na versão de 1950 (como o incêndio da casa ou a chegada do romeiro) não sejam tão sublimados na obra de Botelho, o seu filme consegue refletir mais sombriamente os tempos enturvados do Portugal de então, criando um timbre mais sério e feroz.

O sebastianismo expressa-se numa qualidade de messianismo, sendo que, para António José Saraiva, este tem-se revelado como "uma das persistentes expressões do espírito português, desde Os Lusíadas até ao 25 de Abril inclusive, assumindo várias formas, uma das quais foi o sebastianismo propriamente dito" (Real 1998, 21). Em Nós e a Europa ou as Duas Razões (1994), Lourenço examina a elevação de Portugal a país messiânico, fundamentando que no período em que estivemos subordinados aos castelhanos (1580-1640) "o nosso ser profundo mudou de sinal”, e que, a partir daí, viveríamos numa transtemporalidade, pois o nosso presente usaria o verbo passado, desejando que este se regenera em futuro. Neste sentido, podemos afirmar que a própria temporalidade do Estado Novo era igualmente sebastianista, pois traçou uma suspensão temporal - "eis como 'esperar' se torna um 'movimento contínuo' (...) difere-se para o infinito o momento da ação, 'pensar' ou 'imaginar' substituem-se aos atos reais" (Gil 1995, 33). 
Portanto, o sebastianismo e a transtemporalidade são visíveis em Frei Luís de Sousa através das personagens que vivem limitadas pelas figuras do passado, que, sebastianicamente, poderão modificar o seu futuro. D. João é a mais significativa representação sebastianista na peça e no filme, constituindo-se como uma entidade abstrata e concreta. Esta virtualidade simbólica condiz com uma transpersonalização de Salazar (que, também, Leitão de Barros acentua no final de Camões), onde o chefe do Regime, em termos figurativos e metafóricos, assume as simbologias das personagens que representam o passado glorioso, o sacrifício pela nação e o patriotismo. O sebastianismo é, identicamente, a aparição fundamental dessa política transtemporalizada do Estado Novo, que desenvolve a ideia de um país que subsiste pela memória de si mesmo, fazendo um louvor ao passado. O temperamento sebastianista de Frei Luís de Sousa tornouse, assim, a representação perfeita desse mito de um rei que se tornou o mito de um país, e Salazar a mais feroz tentativa de personificação desse Messias.

\section{Resistência do Cinema Pré-25 de Abril}

Entre 1970 e 1974, uma série de realizadores orientaram-se na tentativa de ruptura, que já se havia consumado em meados dos anos 60 na generalidade dos filmes do Novo Cinema Português, com um cinema politicamente alinhado com o regime $\mathrm{e}$ alheado das transformações político-sociais que sobrevinham. A primavera marcelista e o crescimento de um movimento juvenil, latente e insubmisso, esperançaram a premonição de uma possível mudança, surgindo um cinema prenunciador e sintomático que animava novas expetativas, auxiliado pelo mecenato da Gulbenkian e do recémcriado Centro Português de Cinema.

Durante este período, muitos filmes tiveram a sua exibição interdita por apresentarem questões sensíveis ao Estado Novo, como as referências ao rompimento com a autoridade política e os códigos morais; a crítica à política colonial, ao conflito ultramarino e à polícia política ou a apologia às manifestações estudantis. Podemos atentar a alguns exemplos, como os filmes Índia (1972) e Deixem-me ao Menos Subir às Palmeiras (1972) que trouxeram, a partir do próprio território ultramarino, uma perspetiva anticolonialista; ou, O Mal-Amado (1974) e Perdido por Cem... (1973) que, no contexto da realidade urbana, operaram uma fantasmagorização da Guerra Colonial e a representação de uma juventude forçosamente deserdada das suas idealizações.

O Mal-Amado (1974) de Fernando Matos Silva propõe um olhar sobre a "situação política e social, vista de Campo de Ourique", tendo sido o último filme a ser proibido pela Censura e o primeiro a estrear após o seu termo. Em O Mal-Amado acompanhamos a história de João, um jovem envolvido na mediania dos movimentos estudantis 
e da ideologia de esquerda da época. A dramatização sentimental do filme vai acontecer quando João iniciar uma relação amorosa com Inês, que fatalmente o encaminhará a um final trágico, ao transferir para ele uma paixão obsessiva pelo irmão morto na Guerra Colonial. Os elementos dramáticos ligados à solidão, ao desejo, à posse e à morte são acompanhados pelo retrato de uma juventude desajustada ao conservadorismo e aos códigos morais retrógrados do início dos anos 70, visível em figuras sociais tipificadas como o pai autoritário e intolerante, o filho revoltado (mas inerte) e a mãe e as irmãs subjugadas aos homens da casa.

Em O Mal-Amado, as personagens são afetadas pela mesma nocividade advinda do imperialismo português. Os ferimentos da guerra são especialmente visíveis em Inês, cuja perversão terá a sua expressão maior quando der uma nova figuração ao irmão morto na guerra através do corpo de João. O fantasma do irmão tomará conta deste, quando Inês insistir para que João vista o camuflado do morto, antes de se deitar com ele na cama para uma cena de amor. Desta forma, é desenhada uma das mais poderosas representações da Guerra Colonial em todo o cinema português (Grilo 2006, 87). Corrompido e destruído pelas malhas da ânsia de Império, o som dos sinos indicarão a tragédia do final, quando Inês assassinar João, sendo estas as suas últimas palavras: "No fundo, tu, eu, todos estamos doentes de saudade. Morremos muito cedo voltados para um passado que dizem ser o nosso, sem nunca nos reconhecermos até ao fim, até ao impossível regresso de um irmão morto”.

Desta forma, O Mal-Amado mostra "a imagem do homem português, frustrado de ambições, palavras e desejos, pela mediocridade reacionária, a repressão fascista e a Guerra Colonial. Porque é aí, nessa ideia de mau gosto, que a censura esbarra, ao deparar-se com algo que nos mostra a clandestina ligação entre a patologia do comportamento de Inês e a patologia da guerra colonial” (Grilo 2006, 87). Essa patologia é, portanto, a anormalidade de uma política que insiste no comportamento ilógico e fantasista de imperialismo. Contrariando os tons épicos dos protagonistas de Camões e Frei Luís de Sousa, o herói de $O$ Mal-Amado é prostrado, frustrado e atraiçoado por uma sociedade obrigada a viver em resignação, onde todos estão doentes de saudade de um passado onde verdadeiramente não se reconhecem e perfilham.

À semelhança de O Mal-Amado, Perdido por Cem... (1973), a primeira longa-metragem de António-Pedro Vasconcelos, representa alegoricamente o tabu cinematográfico da Guerra Colonial, tal como o declínio do seu jovem protagonista. Perdido por Cem... tem a mesma chaga d'Os Verdes Anos (1963), a obra de Paulo Rocha realizada dez anos antes, que também narrava a contundente vivência de um jovem da província em Lisboa e o seu relacionamento com uma igual rapariga provinciana. Porém, a brutalidade do final do filme de Rocha ganhará um sentido ainda mais marcado em Perdido por Cem..., pois 
aqui trata-se de um "imenso adeus aos nossos verdes anos", na expressão de Fernando Lopes, onde os jovens do filme "parecem conformar-se com os desígnios imediatos da vida, já que as circunstâncias lhes limitam o futuro e a Guerra do Ultramar espreita cruelmente por entre as imagens" (Pina 1987, 168).

Perdido por Cem... principia com o regresso do seu protagonista a Lisboa, Artur, um jovem de vinte e poucos anos, que retorna após o suicídio do pai, ocorrido durante as férias da família. Por entre as contingências da vivência lisboeta, Artur envolve-se com Joana, uma rapariga da província que conheceu num café à beira da estrada. No final, os dois tentam partir para Roma, porém o antigo namorado desta, regressado da guerra em Angola, persegue-os obcecadamente pela cidade, até matar Joana no aeroporto quase vazio. Quando interrogado pela policia, Artur dirá que não conhecia Joana, seguindo elipticamente a sua vida.

Novamente, tal como em O Mal-Amado, também neste filme há uma fantasmagorização da Guerra Colonial e um final trágico devido a uma obsessão de pertença, aqui representada através da personagem do namorado, uma "poderosa metonímia de toda a guerra colonial e do clima de vigilância repressiva em que o país se encontra mergulhado" (Grilo 2006, 86). A criação desta ambiência acossadora irrompe nos longos planos-sequência que seguem as personagens, contribuindo para "converter a guerra num fantasma opressivo, que tanto se vive nos campos de batalha como na retaguarda metropolitana, onde todos (sem exceção) são milicianos à força" (Grilo 2006, 86).

\section{O Cinema Parricida: Brandos Costumes}

Muitos destes filmes do final do Estado Novo manifestavam uma narrativa relacionada com a morte, percetível em personagens que morriam num sentido alegórico, inscrevendo-se assim naquilo que Bénard da Costa denomina como "necrofilme", uma expressão criada para singularizar as obras deste período, pois "todas elas vão topar na morte e nisso se comprazem como delicioso pungir" (Costa 1976). Desta forma, sobreveio uma espécie de necrofagia no cinema português, que se alimentou, através de simbologias de cessação, das substâncias em decomposição de um regime desfalecido que caminharia para o seu termo.

Neste cinema português funesto há ainda uma outra questão central: a sentença parricida, a morte do Pai, de um "pai comum de todos”. Se em filmes como O Mal-Amado e Perdido por Cem... já adivinhávamos o conflito paternal, sobretudo após a deposição do regime, encontraremos obras onde ocorre a simbólica "morte do pai tirano" (Areal 2011, 30), o derrube edipiano dos vários papéis por onde se divide a autoridade patriarcal. Portanto, neste contexto, Brandos Costumes (1974) de Alberto Seixas Santos, distingue-se ao 
principiar logo com a anunciação de duas mortes - a do Pai da família e do Pai da nação -, uma morte dupla que, dissimuladamente, vamos pressentindo ao longo do filme, voltando a assomar no final, na sequência do enterro de Salazar e do monólogo do Pai moribundo.

Portanto, a questão fundamental de Brandos Costumes é a morte do Pai, numa associação do agregado familiar ao salazarismo, sendo este o primeiro filme que "faz o funeral do antigo regime", não apenas alegoricamente, pelo paralelismo entre estes dois Pais, mas também pela imagem que surge, logo no início, de Salazar morto no caixão em 1970. No entanto, apesar desta contínua referência à morte e ao parricídio, o filme rejeita "o acto violento de morrer e matar que, por outro lado, e em duas outras sequências, caricaturou (a conspirata à mesa do café) ou malogrou (a tentativa do suicídio da filha mais velha)" (Costa 1976). Esta irrealização é aparente no plano final do filme, quando se filma um Terreiro do Paço vazio - onde já havia acontecido o "parricídio" de D. Carlos e da monarquia -, com a câmara colocada na mesma janela donde foram proferidos os discursos de Salazar, fazendo com que o último olhar do filme seja "ainda o olhar do morto (o olhar do Pai)" (Costa 1976). A imagem de um vazio temporário que poderá ser ocupado pelo regresso do fascismo ou pela revolução.

Brandos Costumes está temporalmente entre duas épocas, foi iniciado antes da revolução e finalizado após esta, sendo intercalado por duas expressões - uma documental e coletiva sobre a ascensão, glória e queda do Estado Novo, e, outra, ficcional e familiar -, produzindo assim um contraste entre os mecanismos diretos que o poder político exerce e os seus efeitos circunscritos numa dimensão caseira da pequena/média burguesia. Contudo, a extensão documental não impede que, tal como na ficção familiar, haja fantasia. Na verdade, a simulação do coletivo é visível pelo fato de aparecerem cenas de dois filmes do regime, Chaimite (1953) e A Revolução de Maio (1937), misturadas de forma dissimulada com as imagens documentais, aparentando assim também elas serem documentos de acontecimentos da época e não obras ficcionais. Neste sentido, Seixas Santos deixa subentendido como as manifestações de poder dos discursos de Salazar eram também ficcionais, tratavam-se de grandes encenações de poder.

O filme de Seixas Santos foi filmado entre 1972 e 1973, terminando porém com uma singular transtemporalidade. $\mathrm{O}$ filme finaliza na sala de estar da família, onde enquanto a filha mais nova lê o $\mathrm{Ma}$ nifesto Comunista de Marx, ouvem-se os soldados e os tanques, luzes avermelhadas tomam o espaço interior, a empregada corre para a janela gritando "menina, venha ver os soldados", e, a avó vocifera "os bolcheviques, os bolcheviques". Insolitamente, esta cena foi filmada em 1972, auferindo-lhe assim uma dimensão transtemporal e adivinhativa, pois os seus elementos constituintes remetem diretamente para a Revolução de Abril, que aconteceria apenas dois anos depois. 


\section{5. $O$ Bobo e a Fundação da Nação}

Se algumas obras dos anos 70 eram já premonitórias, tratando de uma forma indireta o desabamento da mitologia identitária nacional, a partir da década de 80, o cinema português iria expressar um discurso claramente crítico e destruidor da hegemonia dos mitos nacionais, como o passado-presente, a cessação do império e o sebastianismo.

Em 1974, o derrube do Estado Novo trouxe a possibilidade de uma confrontação dos portugueses consigo mesmo. O tombo do sonho imperial das colónias, que nos ligava a um passado glorioso, constituiu uma nova realidade, pois representou a contingência de uma necessária reconfiguração mitológica. Neste sentido, alguns cineastas criaram uma espécie de desconstrução exorcista, que tentaria esconjurar os fantasmas do antigo regime e, assim, as representações míticas e simbólicas delatadas por Eduardo Lourenço, e, politizadas pelo salazarismo. Neste sentido, podemos citar algumas obras como Deus, Pátria, Autoridade (1976) e Bom Povo Português (1980) de Rui Simões, Os Demónios de Alcácer Quibir (1976) de José Fonseca ou Acto dos Feitos da Guiné (1980) de Fernando Matos Silva, entre outros.

Partindo deste contexto, O Bobo (1987) de José Álvaro Morais, versa uma analogia entre a edificação do país como reino independente, através da ação de D. Afonso Henriques, e os primeiros anos desencantados após a Revolução dos Cravos, quando a nação ainda se encontrava sob a espetralidade do antigo regime, mas tentava identicamente fundar um novo estado. O Bobo interpela assim o contexto do pós-Revolução de Abril, de um Portugal que já havia percorrido os momentos mais quentes da liberdade, e estaria, naquela altura, a renovar-se das cinzas do 25 de Abril. O filme é, portanto, prenunciador de um desengano, questionamento e desilusão face à "presença fantasmagórica das promessas e das esperanças revolucionárias não cumpridas [que] persegue igualmente o cinema português pósrevolucionário" (Zan e Rodovalho 2014).

A ação do filme acontece no final dos anos 70, nos últimos dias de ensaio da adaptação teatral do romance $O$ Bobo (1843) de Alexandre Herculano, pelo encenador Francisco Bernardes, que também interpreta na peça o papel do bobo Dom Bibas. Aos acontecimentos do passado ligados à fundação da nacionalidade traçados na peça teatral, articulam-se as peripécias quotidianas da "vida real" entre o encenador, a sua família, amigos e atores: a namorada de Francisco, Rita, não compreende a relação oblíqua do seu companheiro com João, um amigo seu de infância que se envolve em negócios obscuros e arriscados para conseguir vender as armas pertencentes aos antigos camaradas revolucionários.

O filme possui uma série de narrativas cruzadas, onde as duas tramas principais - a realidade dos anos 70/80 e a peça teatral -, ri- 
mam internamente entre si, onde um episódio de uma das narrativas verseja e concerta a outra trama. Para além destes dois enredos principais, O Bobo abrange ainda mais ramificações, como o filme a pretoe-branco protagonizado por Rita, as imagens da viagem à Grécia de João ou o episódio traumático passado na infância dos dois amigos. Todas elas estabelecem um tecido de relações, de analogia ou de contradição, alegóricas a este pós-25 de Abril, bem como um temperamento edipiano, tal como vimos anteriormente com o exemplo de Brandos Costumes: "o pai de Francisco suicidou-se enquanto este esperava João no sótão (João representa assim a culpa recalcada); mas Afonso Henriques também não tem pai e, por outro lado, sabe-se que a "morte do pai" ilustrou, no plano alegórico, a aspiração à mudança de regime na cinematografia portuguesa" (Saguenail 2005, 36).

Ainda no final da década de 80 , houve uma outra obra que reproduziu o mesmo contexto histórico d'O Bobo, inscrevendo-se numa espécie de auscultação subtil ao ser nacional coletivo, algo perceptível no seu subtítulo: "uma comédia lusitana". Recordações da Casa Amarela (1989) de João César Monteiro é uma reprodução dilaceradora e impiedosa do país dos anos 80 - no contexto do pós-25 de Abril e da recente adesão à Comunidade Económica Europeia - onde o realizador filma a Lisboa típica e popular, dos bairros antigos e dos residentes desbragados e desregrados. Desta forma, a "degradação da personagem João de Deus reflete a degradação do próprio país, que se constitui a partir do sentimento da perda, quer dos valores materiais, quer dos espirituais" (Cunha 2008). Será na figuração de Stroheim que veremos João de Deus deambular sob o pano de fundo da Lisboa arruinada do Chiado após o seu grande incêndio, a capital destruída e esventrada, como se se trata-se da visão/profecia de uma guerra. Segundo Monteiro, esta figura relaciona-se com uma resistência à pobreza através da possibilidade ficcional de viver uma outra vida pela arte, bem como com uma frustração pós-revolucionária na referência a Otelo Saraiva de Carvalho, conhecido capitão de abril, que na altura se encontrava detido, acusado de ser membro da organização terrorista Forças Populares 25 de Abril. Neste contexto, em forma de apontamento, podemos igualmente convocar a obra de Paulo Rocha, O Desejado ou As Montanhas da Lua (1987), onde o cineasta retrata, em termos mitológicos e imaginários, o cenário da sociedade nacional pós-revolucionária, associando o mito de D. João ao $O$ Conto de Genji de Murasaki Shikibu. Neste filme há uma referência sebastianista - como o próprio título, “o desejado”, indica onde o político Francisco Sá Carneiro, desaparecido na queda de um avião em 1980, encarna a figuração transtemporal de D. Sebastião.

O Bobo tem na sua origem um romance homónimo do romantismo português de Alexandre Herculano (publicado no mesmo ano de Frei Luís de Sousa, em 1843), que evoca as lutas no Condado Portucalense, mais precisamente no espaço simbólico do Castelo de 
Guimarães, cenário por onde se desdobram intrigas amorosas e palacianas, protagonizadas pelo jovem Afonso Henriques, Egas Moniz, D. Tereza ou o Conde de Trava, acabando porém por ser D. Bibas, o bobo da corte, o observador oclusivo e verdadeiro agente da ação do enredo. Ao proferir sobre a origem do seu filme, Morais vai convocar Quem és Tu? de Botelho: "Frei Luís de Sousa, a peça de Garrett que Botelho ali adapta, é um texto que me diz diretamente respeito. Sinto-me muito próximo: mostrar-me este filme é falar de mim mesmo" (Morais 2005). Neste sentido, para o cineasta, os textos de Herculano e Garrett têm este tipo de "exaltação mais inteligente, mais sólida e mais desesperada que a das ideologias do regime de Salazar" (Lemière 2005), e, tal como Eduardo Lourenço observa nas suas teorizações, essa tal exaltação foi contudo "a causa das nossas desgraças. Era o ponto de vista oposto, era a posição que nos fechava. (...) Era essencialmente a formulação ideológica da exaltação nacionalista" (Lemière 2005, 49).

O Bobo foi escrito com o objetivo de criar uma obra de glorificação patriótica no contexto da perda portuguesa da sua primeira colónia, o Brasil, em 1822. O desaparecimento definitivo, e quase total, do império em 1974 foi o mote para José Álvaro Morais encontrar na filmagem da obra de Herculano um paralelo com o país do final da década de 70: "a dura realidade do Portugal pequenino na ponta da Europa, depois de concluída essa missão de que Herculano falava" (Lemière 2005, 49). Por outro lado, O Bobo conclui uma ideia de desistência, percetível sobretudo na figura de João, que antes encerrava o ideal da mudança revolucionária, mas, posteriormente, decidiu vender as antigas armas da resistência a pessoas pouco confiáveis.

Assim, $O$ Bobo não apresenta um país em dois tempos, mas um Portugal transtemporalmente a "um tempo", havendo uma união entre a História coletiva da fundação da nacionalidade e as desventuras individuais da atualidade de então. Para Morais, houve sobretudo uma vontade de falar de qualquer coisa que havia chegado ao fim, pois tal como enuncia Lourenço: “1974-1975 marca o fim do Portugal de Salazar, da exaltação da pátria. É o fim da dominação de uma ideologia morta com o 25 de Abril e a descolonização: a fundação de Portugal como uma história exagerada” (Lemière 2005, 49).

\section{Non ou a Vã Glória de Mandar: Desconstrução das Mitologias Nacionais}

Após a "Tetralogia dos Amores Frustrados", Manoel de Oliveira encetaria uma meditação sobre a História do país e o sentido histórico coletivo, que se iniciou com Le Soulier de Satin (1985), prosseguindo em Non ou a Vã Glória de Mandar (1990), Palavra e Utopia (2000), Um Filme Falado (2003), O Quinto Império: Ontem como Hoje (2004), 
Cristóvão Colombo: O Enigma (2007), Painéis de São Vicente de Fora: Visão Poética (2009) e O Velho do Restelo (2014).

Non ou a Vã Glória de Mandar (1990) compreende uma ampla reflexão sobre a História portuguesa. A Guerra Colonial, o momento do iminente desabamento do império, é o longo cordão que liga vários nós que vão assomando à narrativa central. Esses nós são os diversos desastres militares portugueses, como a recusa da civilização romana pelos lusitanos; a aspiração a um grande reino ibérico; o desejo de um Quinto Império por D. Sebastião; ou, a ambição de conservar os territórios da Expansão Marítima. Este longo fio é narrado pelo alferes Cabrita a um grupo de soldados durante as intermitências dos combates coloniais, indo desembocar numa contracena final que liga o desar de Alcácer-Quibir ao 25 de Abril.

Este exercício de rememoração inicia-se com uma longa cena onde vários soldados seguem sentados num camião aberto pelas estradas de terra batida africanas. Nesta sequência, esta unidade de militares conversam entre si, iniciando-se depois a incursão pelos momentos históricos. Trata-se, portanto, de um movimento sobre um outro movimento: a movimentação do camião que avança no presente é simultânea de uma movimentação que vai retroceder em direção ao passado. Na entrevista O Céu é Histórico (Preto 2008, 6), feita por Serge Daney e Raymond Bellour a Oliveira, falava-se, relativamente a esta cena, de uma renovação dada ao contra-campo, um posicionamento entre os corpos e a câmara que concebe um campo/contracampo entre o presente e o passado, a que se pode acrescentar uma estrutura fragmentada e transtemporalizada - um movimento de passagem que nos leva, paradoxalmente, do cenário da Guerra Colonial à História portuguesa, ao presente e ao passado -, lembrando a composição da epopeia clássica, ainda que Non se apresente como um Os Lusíadas invertido. Aliás, o filme de Oliveira desmancha um possível tom épico e epopeico, visível exemplarmente na falsidade das perucas que os soldados de Viriato usam, que contrariam o caráter heroico de filmes como Camões ou Frei Luís de Sousa.

Non edifica-se como uma reflexão acerca da missão histórica do homem em combate, um monumento fílmico ao soldado desconhecido, através dum retrato transtemporal e duma transpersonalização de cada um destes soldados em África, que irão representar os vários militares das narrações do passado, criaturas dessa mesma vanidade. Na descrição de Bénard da Costa, estes soldados encarnam assim "outros fantasmas, porventura a idêntica visão sem perspectiva da representação mais célebre da nossa coralidade colectiva: os Painéis de S. Vicente de Fora" (Costa, 2008, 124), as mesmas imagens que, como vimos no filme de Leitão de Barros, dão a Camões a epifania para a criação d'Os Lusíadas.

Segundo Oliveira, Non é constituído numa forma espiral, pois há um "fio que se mantém durante um longo momento, mas já não é 
o mesmo momento" (Preto 2008), mas, também, numa forma circular, como no desfecho dos vários episódios ou na transpersonalização das personagens, uma configuração que se transformou na forma por excelência deste movimento exorcista do pós-25 de Abril. Um Adeus Português (1985) de João Botelho, é o primeiro filme de ficção realizado em Portugal sobre a Guerra Colonial, tratando-se de uma obra de exorcismo, visível no facto do realizador se ter debatido quase durante um ano para convencer o exército português a participar. No filme, as grandes relações da obra também são entendidas num sentido circular transtemporal, entre o presente e o passado, onde "Portugal se revê em África, os filhos nos pais, os vivos nos mortos, a guerra na paz, o cinema na vida e na memória” (Grilo 2001, 96).

A questão da transtemporalidade e da circularidade na guerra já era manifesta num outro filme de Oliveira: O Acto da Primavera (1961). Este filme estreou no mesmo ano em que estalou a Guerra Colonial em Angola, e apesar das imagens do conflito africano serem inexistentes, Oliveira conseguiu dialogar a Paixão de Cristo com este período que se iniciara em Portugal, através de um retalho de imagens que vão da explosão da bomba atómica à Guerra do Vietname. Em Non, Oliveira retomaria estas proposições, como a transtemporalidade e transespacialidade dos acontecimentos (da Curalha a Jerusalém, da Guerra Colonial aos restantes conflitos), inscrevendoos num mesmo retorno à ambição e tragédia.

O motor inicial de Non é um enigmático plano-sequência que revela uma árvore gigantesca que em vão se tenta filmar, criando a tensão de um elemento que, simultaneamente, visível e oculto, mantém-se misterioso. A denominação do filme cita um excerto do "Sermão da Terceira Quarta-Feira da Quaresma", pregado por António Vieira, sendo a terminada configuração dessa circularidade, cuja natureza é uma recorrência inútil: "Terrível palavra é um Non. Não tem direito, nem avesso. Por qualquer lado que a tomeis, sempre soa e diz o mesmo. Lede-o do princípio para o fim, ou do fim para o princípio, sempre é non."

O realizador vai ligar o "non" de Vieira ao "vã glória de mandar" do episódio negativista d'O Velho do Restelo de Os Lusíadas, convocando posteriormente de novo Camões, ao encenar a narrativa da Ilha dos Amores, o único episódio que contraria o teor derrotista e trágico dos restantes. Esta Ilha tem na obra de Camões uma dimensão transtemporal e profética, pois os navegadores portugueses partem de lá com uma visão do seu porvir, sabendo das suas futuras grandezas no Oriente. Aliás, a Ilha é em si um espaço fora do tempo, pois está num tempo que não é o da História, é o tempo anacrónico da mitologia.

Non termina com duas visões devaneadoras do moribundo alferes Cabrita num hospital de campanha que aproximam AlcácerQuibir ao 25 de Abril, pois para Oliveira "Alcácer-Quibir é o ponto 
fulcral, é o Non da nossa História" (Preto 2008). A primeira visão de Cabrita mostra a sua própria transfiguração em D. João nos despojos de Alcácer-Quibir - ou seja, na sua representação como Ninguém, na referência a Frei Luís de Sousa -, convocando assim toda a simbologia que resta do vazio do presente e do futuro, dum Portugal reduzido ao possível nada de si mesmo. A segunda visão do alferes liga a realidade ao sonho: a visão do ressurgimento de D. Sebastião, que envolto em nevoeiro, desembainha a sua espada e inverte a lâmina, apertando-a entre as mãos: vemos escorrer o seu sangue pela ponta da arma, tal como vemos simultaneamente o sangue do alferes pingar nos tubos a que está ligado. A inversão da espada, nas palavras de Oliveira, "inverte o sentido de heroico, de matar e de vencer, para o sentido de paz, de compaixão, de amor, de harmonia. Da dádiva” (Preto 2008).

A circularidade de Non concorda com a forma esférica de um passado messiânico, onde é "difícil distinguir se o nosso passado é que é o nosso futuro ou se o nosso futuro é que é o nosso passado" (Real 1998, 158). Em Non, a escrita da História aproxima-se da inscrição em reverso da história dos vencidos de Walter Benjamin, onde o despontar de um passado desmemoriado tem a função de o conservar e libertar. $\mathrm{O}$ presente recupera o seu passado mais esquecido, e este movimento influi na possibilidade de um futuro diferente, tal como o final de Non sugere. O 25 de Abril simbolizou a perda do sonho da colonização e do império, reduzindo Portugal quase somente ao seu território europeu. Ao conceber uma genealogia que liga a chegada de D. Sebastião ao 25 de Abril, Oliveira une um aparecimento messiânico a um movimento pacífico que trouxe a possibilidade de desfazer toda a História anterior e os seus mitos. Assim, Non convoca Eduardo Lourenço, ao edificar-se como uma obra da "inevitável derrota, e essa derrota não é só a de um país (...) a da ilusão do sentido que cada país busca na sua história ou na história que de si próprio conta" (Costa 2008, 121).

\section{Considerações Finais}

As obras analisadas em $O$ Cinema Português, o Transtemporal e o Mito inserem-se num conjunto variado de representações do país, que têm em comum o facto de interrogarem simultaneamente o passado e o futuro, a partir do presente. Portanto, foi percetível observar a vastidão do conjunto de obras cinematográficas que trabalham, analogamente, a temporalidade e a mitologia nacional, expressando assim a grande capacidade construtora, desmanteladora e reinventora do cinema português na reformulação incessante de um património imaginário e mitificado comum. Neste sentido, foi possível analisar estas questões trilhando parte da História do cinema e da realidade político-social em Portugal: a cultura patriótica do cinema ao serviço do Estado, de Camões e Frei Luís de Sousa; a crítica funesta, parricida e dissimulada do país, no final do regime autoritário, em Brandos Cos- 
tumes, O Mal Amado e Perdido por Cem...; a desilusão dos mitos pósrevolucionários, democráticos e europeus em $O$ Bobo, Recordações da Casa Amarela e Non ou Vã Glória de Mandar. Portanto, procurou-se perspetivar as inúmeras rimas e contra-rimas existentes nestas cinematografias, exemplificadas nas diversas representações da transtemporalidade, manifestas nas personagens e mitos transhistóricos como o sebastianismo e o imperialismo, na profetização e sintomático ou na representação da circularidade messiânica.

Podemos ainda atentar a outras questões que derivam destes temas centrais, como é o caso dos confrontos existentes nas diversas representações da História no cinema português, nomeadamente, a adaptação histórico-literária mais estanque em Frei Luís de Sousa, mas mais livre em Quem és Tu? e O Bobo; a sublimação do "herói” em Camões na década de 40, contrastando com o cinema da década de 70 e do pós-25 de Abril, onde há uma decadência heroica; ou, a conceção de filmes históricos mais lendários durante o Estado Novo, contrariando a tendência posterior, a partir da década de 80 , de uma maior exatidão coincidente com um desejo, mais prosaico embora não menos significativo (ou mesmo alegórico) de objetividade crítica. Cumpre referir que o século XXI tem visto surgir obras, como $A$ Costa dos Murmúrios (Margarida Cardoso, 2004), Juventude em Marcha (Pedro Costa, 2006), Tabu (Miguel Gomes, 2012) ou A Última Vez que Vi Macau (João Pedro Rodrigues e João Rui Guerra da Mata, 2012) que lidam precisamente com as memórias do Estado Novo ou com o pós-colonialismo, e onde novamente se verifica uma subjetivação histórica que precisa, ainda assim, de ser perspetivada e entendida na especificidade do seu contexto de intervenção. Estes são apenas alguns exemplos das possíveis conclusões desta investigação, sem descurar que outras possibilidades de interrogação e desenvolvimento ficaram, inevitavelmente, em aberto, sobretudo porque tanto a transtemporalidade como a mitologia identitária são temas, eles próprios com múltiplas ramificações, difusos, inconclusivos, subtilmente transitivos.

\section{BIBLIOGRAFIA}

Areal, Leonor. 2011. Cinema Português - Um País Imaginado Vol. II Após 1974. Lisboa: Edições 70.

Ash, Timothy Garton. 2005. "El pasado nos persegue”. El País, 6-112005.

Costa, João Bénard da. 1991. Histórias do Cinema. Lisboa: INCM.

Costa, João Bénard da. 2008. Manoel de Oliveira: Cem Anos. Lisboa: Cinemateca Portuguesa - Museu do Cinema. 
Costa, Bénard da. 1975. "A propósito de "Brandos Costumes" filme de Alberto Seixas Santos". In Brandos Costumes: Um Filme de Alberto Seixas Santos. Lisboa: Centro Português do Cinema, Casa Portuguesa.

Cunha, Paulo. 2008. A cidade cinemática de João de Deus: espaço, cenário e estética na obra de João César Monteiro.

http://www.compos.org.br/seer/index.php/ecompos/article/viewFile/246/290

Epifânio, Renato. De José Marinho a Eduardo Lourenço e Miguel Real, passando por Álvaro Ribeiro e Agostinho da Silva - breve reflexão sobre o nosso "atraso". Consultado em 29-08-2014:

http://www.eduardolourenco.com/6_oradores/oradores_PDF /Renato_Epifanio.pdf

Geada, Eduardo. 1977. O Imperialismo e o Fascismo no Cinema. Lisboa: Moraes.

Gil, José. 1995. Salazar: a Retórica da Invisibilidade. Lisboa: Relógio D’Água.

Grilo, João Mário. 2006. O Cinema da Não-Ilusão. Lisboa: Horizonte.

Lourenço, Eduardo. 2007. O Labirinto da Saudade, Lisboa, Gradiva.

Lourenço, Eduardo. 2001. Portugal como Destino seguido de Mitologia da Saudade. Lisboa: Gradiva.

Lemière, Jacques. 2005. "Conversa(s) com José Álvaro Morais". In José Álvaro Morais (coord. Anabela Moutinho). Faro: Ministério da Cultura.

Lemière, Jacques. 2009. "Terra a Terra": O Portugal e o Cabo Verde de Pedro Costa. In Cem Mil Cigarros - Os Filmes de Pedro Costa (coord. Ricardo Matos Cabo). Lisboa: Orfeu Negro.

Miranda, Rui. 2013. Re(in)sistindo: Textos e Contextos da Casa Amarela. Consultado em 31/08/2014: www.elyra.org/index.php/elyra/article/view/33/36

Pina, Luís de. 1987. Histórias do Cinema Português. Lisboa: Mem Martins: Europa-América.

Preto, António. 2013. "Brandos Costumes: O drama da família pequeno-burguesa na encruzilhada do século XX". In FFFilm Project, Porto, Balleteatro.

Preto, António. 2008. Manoel de Oliveira: O Cinema Inventado à Letra. Porto: Fundação de Serralves / Jornal Público.

Real, Miguel. 1998. Portugal - Ser e Representação. Lisboa: DIFEL.

Rosas, Fernando. 1998. História de Portugal: O Estado Novo (19261974). Lisboa: Editoral Estampa. 
Saguenail. 2005. Reinos Desencantados - Um olhar sobre a obra de José Álvaro Morais. Santa Maria da Feira: Festival de Cinema LusoBrasileiro de Santa Maria da Feira.

Seixas, Alberto Santos. 1975. Brandos Costumes: Um Filme de Alberto Seixas Santos. Lisboa: Centro Português do Cinema, Casa Portuguesa.

Sobral, José Manuel. 2006. Memória e Identidade Nacional: considerações de carácter geral e o caso português. Consultado em 28-82014, em:

http://www.ics.ul.pt/publicacoes/workingpapers/wp2006/w p2006_4.pdf

Torgal, Luís Reis. 2009. Estados Novos, Estado Novo. Coimbra, Coimbra Editora.

Torgal, Luís Reis (ed.). 2001. O Cinema Sob o Olhar de Salazar. Lisboa: Temas e Debates.

Zan, Vitor, e, Rodovalho, Beatriz. 2014. Revolução e cinema: o exemplo português: http://aim.org.pt/ojs/index.php/revista/article/view/85/html

Zerubavel, Eviatar. 2003. Time Maps: Collective Memory and the Social Shape of the Past. Chicago, The University of Chicago Press. 